\title{
Association study of the $C 3$ gene with adult and childhood asthma
}

\author{
Hiroki Inoue $\cdot$ Yoichi Mashimo $\cdot$ Makiko Funamizu $\cdot$ Naoki Shimojo $\cdot$ Koichi Hasegawa \\ Tomomitsu Hirota $\cdot$ Satoru Doi $\cdot$ Makoto Kameda $\cdot$ Akihiko Miyatake $\cdot$ Yoichi Kohno \\ Yoshitaka Okamoto $\cdot$ Mayumi Tamari $\cdot$ Akira Hata $\cdot$ Yoichi Suzuki
}

Received: 29 November 2007 / Accepted: 16 May 2008/Published online: 20 June 2008

(C) The Japan Society of Human Genetics and Springer 2008

\begin{abstract}
Bronchial asthma (BA) is a multifactorial disorder, the development of which is affected by both environmental and genetic factors. The complement system plays an important role in immunological response against invading microorganisms. It has been shown that complement-C3-deficient mice have reduced inflammation of asthmatic airways. Previously, we reported the association of four single nuclear proteins (SNPs) in the exons of the $C 3$ gene with childhood and adult BA. The $C 3$ gene, however, is a large gene, and functional SNPs associated with susceptibility to BA have not yet been identified. We analyzed
\end{abstract}

H. Inoue · Y. Mashimo · M. Funamizu · A. Hata

Y. Suzuki (ه)

Department of Public Health, Graduate School of Medicine, Chiba University, 1-8-1 Inohana, Chuo-ku,

Chiba 260-8670, Japan

e-mail: ysuzuki@faculty.chiba-u.jp

K. Hasegawa $\cdot$ T. Hirota $\cdot$ M. Tamari

Laboratory for Genetics of Allergic Diseases,

SNP Research Center, The Institute of Physical

and Chemical Research (RIKEN), Yokohama, Japan

N. Shimojo · Y. Kohno

Department of Pediatrics, Graduate School of Medicine,

Chiba University, Chiba, Japan

Y. Okamoto

Department of Otolaryngology, Graduate School of Medicine,

Chiba University, Chiba, Japan

S. Doi · M. Kameda

Department of Pediatrics, Osaka Prefectural Medical

Center for Respiratory and Allergic Diseases, Habikino, Japan

A. Miyatake

Miyatake Asthma Clinic, Osaka, Japan
26 SNPs in the $C 3$ gene and its promoter region to narrow down the regions showing association with childhood and adult BA. Childhood and adult atopic BA patients and healthy child and adult controls were recruited from urban cities in Japan and genotyped. In SNP analysis, an SNP (SNP24, rs11569562) located in intron 31 of the $C 3$ gene was associated with adult BA [corrected $P\left(P_{\text {cor }}\right)=0.030$ ]. In linkage disequilibrium (LD) block 4 spanning exons 24-41, the frequency of the CCC haplotype in adult BA was significantly higher than that in adult controls $\left(P_{\text {cor }}=\right.$ 0.038). Neither the SNP nor the haplotype showing association with adult BA demonstrated a significant association with serum total immunoglobulin E (IgE) level in BA patients and controls. Our results suggest that LD block 4 confers susceptibility to adult BA with mechanisms relevant to the effector phase of allergic inflammation.

Keywords Complement $\cdot C 3$ gene $\cdot$ Asthma $\cdot$ SNP . Haplotype $\cdot$ Association · Total IgE

\section{Introduction}

Bronchial asthma (BA) is an inflammatory airway disease, the development of which is affected by both environmental and genetic factors (Barnes and Marsh 1998). The complement system belongs to the groups of ancient pattern-recognition systems and sensing exogenous (microorganisms) and endogenous (altered-self) danger-associated molecular patterns (Kohl and WillsKarp 2007). The three pathways of complement activation are the classical, alternative, and lectin pathways, and all complement activation pathways converge at $\mathrm{C} 3$. On activation, $\mathrm{C} 3$ breaks into a large $\mathrm{C} 3 \mathrm{~b}$ fragment and a small C3a fragment that is called anaphylatoxin. C3b can 
form C5 convertase and activate another component of the complement, C5. C5 is cleaved into C5a anaphylatoxin and $\mathrm{C} 5 \mathrm{~b}$, and both fragments exert physiological roles. Both anaphylatoxins also show proinflammatory and immunoregulatory actions. It has been shown that complement-C3-deficient mice have reduced inflammation of asthmatic airways (Barrington et al. 2001; Kohl 2001; Muller-Eberhard 1988). Mice and guinea pigs lacking the $\mathrm{C} 3 \mathrm{a}$ receptor $(\mathrm{C} 3 \mathrm{aR})$ essential for $\mathrm{C} 3 \mathrm{a}$ action were protected against bronchoconstriction, airway hyperresponsiveness (AHR), and airway inflammation developing after allergen challenge (Bautsch et al. 2000; Drouin et al. 2002; Humbles et al. 2000). Compared with wild-type mice, C3-deficient mice also exhibit diminished AHR and lung eosinophilia when challenged with an allergen (Drouin et al. 2001). They also showed decreased numbers of interleukin (IL)-4-producing lung cells and decreased serum-antigen-specific immunoglobulin E (IgE) levels. Dendritic cells (Zhou et al. 2007) and activated $\mathrm{T}$ cells express $\mathrm{C} 3 \mathrm{a}$ receptor (Werfel et al. 2000), and C3 and C3a have been shown to regulate interactions between dendritic and $\mathrm{T}$ cells (Kawamoto et al. 2004; Zhou et al. 2007). These results suggested that the $\mathrm{C} 3$ pathway is involved in allergen sensitization. In BA patients, increased levels of $\mathrm{C} 3 \mathrm{a}$ (Humbles et al. 2000; Krug et al. 2001) and C5a (Krug et al. 2001) were observed in bronchoalveolar lavage fluid after segmental allergen provocation, suggesting involvement of the complement system in allergen-induced airway inflammation in humans. Elevation of plasma C3a level was observed in BA patients on acute exacerbation (Nakano et al. 2003). These data are consistent with the notion that the C3 gene plays an important role in allergic sensitization and allergic inflammation. Furthermore, the C3 gene is located at chromosome $19 \mathrm{p}$, where several studies suggested linkage to BA and related phenotypes (Blumenthal et al. 2004; Lee et al. 2000; Venanzi et al. 2001). Therefore, the $C 3$ gene is a strong candidate gene for allergic BA.

Our previous analysis of four single nucleotide polymorphisms (SNPs) in exons of the $C 3$ gene suggested that variations of this gene conferred susceptibility to both childhood and adult BA (Hasegawa et al. 2004). Barnes et al. reported that a haplotype spanning introns 19-23 showed significant association with BA, log (total $\operatorname{IgE}$ ) and $\log$ [interleukin (IL)-13]/log [interferon (IFN)- $\gamma$ ] (Barnes et al. 2006). The $C 3$ gene, however, is a large gene consisting of 41 exons and containing hundreds of SNPs; thereby, further investigation is necessary to identify functional SNPs conferring susceptibility to BA. In this study, we analyzed 26 SNPs of the $C 3$ gene to narrow down the regions showing association with childhood and adult BA.

\section{Methods}

Subjects

All participants were Japanese. Three hundred and fortysix childhood BA patients, 518 adult BA patients, and 550 healthy adult controls were recruited in Osaka City area, Japan. Details of these patients are described in a previous report (Nakashima et al. 2006). All participants with BA were diagnosed and selected by physicians according to the American Thoracic Society (ATS) criteria and using questionnaires based on the recommendation of the ATS, Division of Lung Disease (ATS-DLD) (Ferris 1978). In brief, patients showed repeated episodes of at least one of the following symptoms: cough, wheezing, shortness of breath, chest tightness, and sputum production. Spirometry was performed in all patients to confirm the obstructive pattern of the lung function and response to a bronchodilator. Improvement of their forced expiratory volume in $1 \mathrm{~s}$ $\left(\mathrm{FEV}_{1}\right)$ measurement was at least $12 \%$ after $\beta_{2}$ agonist inhalation. The diagnosis of atopic BA was based on one or more positive skin-scratch-test responses to a range of seven common allergens in the presence of a positive histamine control and a negative vehicle control. The seven allergens were house dust, Felis domesticus dander (Feld), Canis familiaris dander, Dactylis glomerata, Ambrosia, Cryptomeria japonica, and Alternaria alternata. The numbers of atopic childhood and adult BA were 304 and 371 , respectively (Table 1). In this study, we only analyzed atopic BA patients. As child control subjects, 411 child volunteers with ages between 6 and 12 years (male:female $=1.0: 1.04)$ were recruited in Chiba City, Japan. Total and eight specific IgE levels in serum were measured in this group (Dermatophagouides pteronyssinus, C. familiaris, $F$. domesticus, A. alternata, C. japonica, D. glomerata, egg white, golden/black bellied/Hungarian hamster). Questionnaires based on the International Study of Asthma and Allergies in Childhood (Asher et al. 1995) were used to exclude children with BA and/or atopic dermatitis. Three

Table 1 Clinical characteristics of patients and controls

\begin{tabular}{lllll}
\hline & $\begin{array}{l}\text { Childhood } \\
\text { asthma }\end{array}$ & $\begin{array}{l}\text { Adult } \\
\text { asthma }\end{array}$ & $\begin{array}{l}\text { Child } \\
\text { control }\end{array}$ & $\begin{array}{l}\text { Adult } \\
\text { control }\end{array}$ \\
\hline Number & 304 & 371 & 333 & 550 \\
Age mean (years) & 9.69 & 45.13 & 9.22 & 44.57 \\
Age range (years) & $4-15$ & $20-75$ & $6-12$ & $20-75$ \\
Gender (male:female) & $1.54: 1.0$ & $1.11: 1.0$ & $1.0: 1.04$ & $2.81: 1.0$ \\
$\begin{array}{l}\text { Atopic asthma (\%) } \\
\text { Mean total IgE }\end{array}$ & 100 & 100 & & \\
$\quad 2.66$ & 2.54 & 1.90 & $\mathrm{ND}$ \\
\hline log (IU/ml)] & & & & \\
\hline
\end{tabular}

$I g E$ immunoglobulin $\mathrm{E}, N D$ not determined 
hundred and thirty-three children were used as a child control group in association studies. If atopy was defined as those who showed positive specific $\operatorname{IgE}(>0.35 \mathrm{IU} / \mathrm{ml})$ to one or more allergens, $71 \%$ of the child controls were atopic. Details of the adult controls were described previously (Nakashima et al. 2006). Adult volunteers were interviewed by physicians, and those who were diagnosed as having BA, atopic dermatitis, and/or allergic rhinitis were excluded from the adult control group. Measurement of serum IgE levels and skin-prick tests were not performed in the adult controls. All patients and volunteers provided written informed consent to participate in the study in accordance with the rules of the process committee at the SNP Research Center (RIKEN). This study was approved by the ethics committee of Chiba University Graduate School of Medicine.

\section{Screening and selection of SNPs}

We previously investigated four SNPs in the exons of the C3 gene (Hasegawa et al. 2004): 912G/A, 1692AG, 1936GA, and $4896 \mathrm{CT}$ in our previous paper, which correspond to SNP6, SNP7, SNP13, and SNP25, respectively, in this paper (Table 2). SNP25 showed association with mite-positive childhood BA and adult BA. Because SNP25 is located in exon 41, the last exon of the $C 3$ gene, SNPs located around this exon were intensively investigated (SNP17-SNP26). We searched the dbSNP database to list up SNPs with the following criteria: minor allele frequency was more than 0.3 , and distance of the nearest two SNPs did not exceed $2 \mathrm{kbp}$. Considering the potential importance of the gene's promoter region for gene expression, where several regulatory elements have been reported, we searched SNPs up to $5 \mathrm{kbp}$ upstream of exon 1. Four SNPs (SNP1-SNP4) were identified. In addition, we included SNP14, SNP15, and SNP16 in this study to confirm the results of Barnes et al. (2006). To estimate the linkage disequilibrium (LD) status of these SNPs, we genotyped them in 96 adult controls. Haploview 3.32 program (Barrett et al. 2005) was used to show an LD map. LD block was defined with the solid spine of the LD method implemented in the Haploview program. Of the 26 SNPs investigated, 24 composed four LD blocks (Fig. 1). We selected tag SNPs from each LD block with the aid of the Tagger routine incorporated in the Haploview program.

\section{Genotyping}

Genomic DNA was prepared from whole blood samples using a standard protocol. Whole genome amplification was performed using the illustra GenomiPhi V2
Table 2 Locations and allele frequencies of single nucleotide polymorphisms (SNPs) of the $C 3$ gene

\begin{tabular}{|c|c|c|c|c|c|}
\hline SNP & Location & $\begin{array}{l}\text { Allele } \\
(1 / 2)^{\mathrm{a}}\end{array}$ & Position $^{\mathrm{b}}$ & $\begin{array}{l}\text { Minor allele } \\
\text { frequency } \\
(\%)^{\mathrm{c}}\end{array}$ & $\begin{array}{l}\text { dbSNP } \\
\text { number }\end{array}$ \\
\hline SNP1 & Promoter & $\mathrm{T} / \mathrm{C}$ & 6678365 & 0.330 & rs171094 \\
\hline SNP2 & Promoter & $\mathrm{C} / \mathrm{T}$ & 6674037 & 0.157 & - \\
\hline SNP3 & Promoter & $\mathrm{A} / \mathrm{G}$ & 6673635 & 0.298 & rs163913 \\
\hline SNP4 & Promoter & $\mathrm{A} / \mathrm{C}$ & 6673022 & 0.306 & rs339392 \\
\hline SNP5 & Intron 2 & $\mathrm{~A} / \mathrm{G}$ & 6669534 & 0.270 & rs 2250656 \\
\hline SNP6 & Exon 9 & G/A & 6663291 & 0.426 & rs2230201 \\
\hline SNP7 & Exon 14 & G/A & 6669848 & 0.468 & rs2230204 \\
\hline SNP8 & Exon 14 & G/A & 6663704 & 0.414 & rs2230205 \\
\hline SNP9 & Intron 14 & G/A & 6660074 & 0.148 & rs11569429 \\
\hline SNP10 & Intron 14 & G/A & 6660050 & 0.016 & rs4807984 \\
\hline SNP11 & Intron 17 & $\mathrm{~A} / \mathrm{G}$ & 6656246 & 0.403 & rs11672613 \\
\hline SNP12 & Intron 19 & $\mathrm{~A} / \mathrm{C}$ & 6648829 & 0.134 & rs366510 \\
\hline SNP13 & Exon 21 & $\mathrm{C} / \mathrm{T}$ & 6648406 & 0.064 & rs423490 \\
\hline SNP14 & Intron 23 & $\mathrm{C} / \mathrm{T}$ & 6647342 & 0.128 & rs2287848 \\
\hline SNP15 & Intron 23 & $\mathrm{C} / \mathrm{T}$ & 6647178 & 0.371 & rs10410674 \\
\hline SNP16 & Intron 23 & $\mathrm{C} / \mathrm{G}$ & 6646001 & 0.435 & rs 10402876 \\
\hline SNP17 & Intron 33 & G/A & 6634846 & 0.436 & rs344549 \\
\hline SNP18 & Intron 33 & $\mathrm{C} / \mathrm{G}$ & 6633953 & 0.441 & rs344550 \\
\hline SNP19 & Intron 33 & $\mathrm{~T} /-$ & 6633534 & 0.446 & rs11569553 \\
\hline SNP20 & Intron 35 & $\mathrm{~A} / \mathrm{G}$ & 6631937 & 0.468 & rs344552 \\
\hline SNP21 & Intron 35 & $\mathrm{C} / \mathrm{A}$ & 6631928 & 0.394 & rs344553 \\
\hline SNP22 & Intron 36 & $\mathrm{~A} / \mathrm{G}$ & 6630563 & 0.457 & rs 2277983 \\
\hline SNP23 & Intron 36 & G/A & 6630511 & 0.447 & rs2277984 \\
\hline SNP24 & Intron 38 & $\mathrm{~T} / \mathrm{C}$ & 6629753 & 0.456 & rs 11569562 \\
\hline SNP25 & Exon 41 & $\mathrm{C} / \mathrm{T}$ & 6628989 & 0.447 & rs4807893 \\
\hline SNP26 & $3^{\prime}$ Downstream & $\mathrm{T} / \mathrm{G}$ & 6627442 & 0.414 & rs379527 \\
\hline
\end{tabular}

\footnotetext{
${ }^{a}$ Base expressed in the direction the gene

b Based on National Center for Biotechnology Information (NCBI) Build 35.1 reference group label

${ }^{\text {c }}$ In 96 adult control subjects
}

amplification kit (GE Healthcare, Buckinghamshire, UK) according to the manufacturer's standard protocol. Amplified deoxyribonucleic acid (DNA) was typed by allele-specific polymerase chain reaction (AS-PCR) using either the modified TaqMan AS amplification (TaqManASA) method (Fujii et al. 2000) or SYBR Green detection. The primer and TaqMan probe sequences are shown in Table 3. For the TaqMan-ASA method, $2 \times$ Platinum qPCR SuperMix-UDG (Invitrogen, Carlsbad, CA, USA) was used as master mix, whereas $2 \times$ Platinum SYBR Green qPCR SuperMix-UDG (Invitrogen) or $2 \times$ SYBR Green Supermix (Bio-Rad, Hercules, CA, USA) (for only SNP24) was used for AS-PCR together with SYBR Green detection. For the ASA method, the PCR mixture contained $5 \mu \mathrm{l}$ of $2 \times$ PCR master mix, $0.4 \mu \mathrm{M}$ of each PCR 


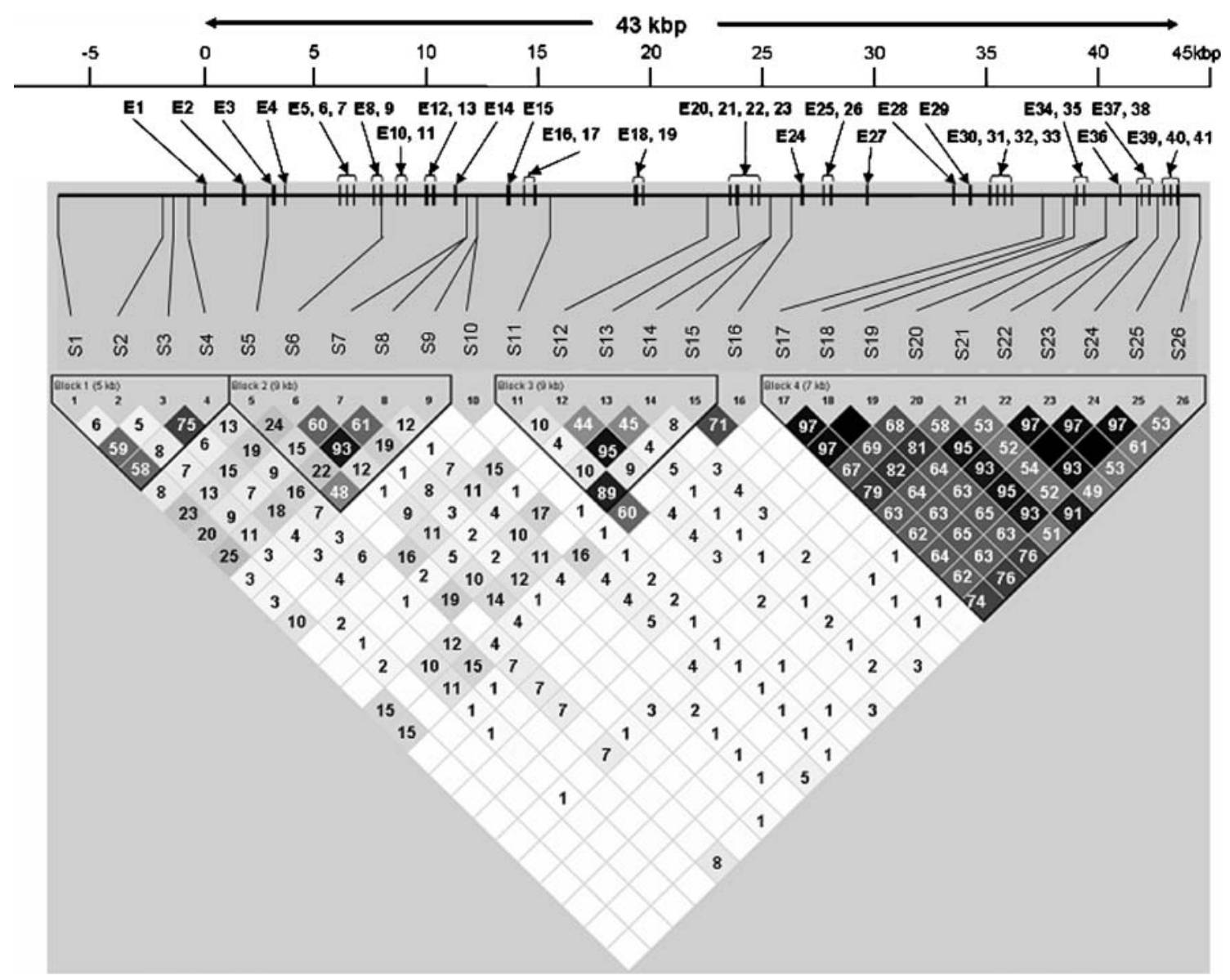

Fig. 1 Structure of the $C 3$ gene and location of single nucleotide polymorphisms (SNPs) and their linkage equilibrium (LD) map. Exons are indicated by black boxes. Numbers starting with $E$ stand for exons and those starting with $S$ for SNPs. Pair-wise LD $\left(r^{2}\right)$ was

primer, $0.12 \mu \mathrm{M}$ of the TaqMan probe (when needed), and $5 \mathrm{ng}$ of amplified template DNA in a final volume of $10 \mu \mathrm{l}$. The samples were analyzed using an ABI PRISM 7000 Sequence Detector System (Applied Biosystems, Foster City, CA, USA) and Chromo4 Real-Time System (Bio$\mathrm{Rad})$. The thermoprofile was $50^{\circ} \mathrm{C}$ for $2 \mathrm{~min}, 95^{\circ} \mathrm{C}$ for 2 min, then 45 cycles of $95^{\circ} \mathrm{C}$ for $15 \mathrm{~s}$ and $60^{\circ} \mathrm{C}$ for $30 \mathrm{~s}$ (for SNP4: 45 cycles of $95^{\circ} \mathrm{C}$ for $15 \mathrm{~s}, 55^{\circ} \mathrm{C}$ for $30 \mathrm{~s}$, and $60^{\circ} \mathrm{C}$ for $30 \mathrm{~s}$ ). For SNP2, PCR was initially performed using 0.2 $\mu \mathrm{M}$ of each first PCR primers and Taq DNA polymerase (Promega, Madison, WI, USA) according to the manufacturer's standard protocol. The thermoprofile of the first PCR was $95^{\circ} \mathrm{C}$ for $3 \mathrm{~min}$, followed by 20 cycles at $95^{\circ} \mathrm{C}$ for $20 \mathrm{~s}, 60^{\circ} \mathrm{C}$ for $30 \mathrm{~s}$, and $72^{\circ} \mathrm{C}$ for $7 \mathrm{~min}$. In the second PCR (TaqMan-ASA method), a reaction mixture of the first PCR diluted tenfold with water was used as a template. Because an SNP was located within the sequence where the AS primer for SNP9 was designed, two primers were mixed and used in the reaction mixture for SNP9 (Table 3). estimated from 96 control subjects. LD blocks were defined by the solid spine of LD using the Haploview program. Number in each cell represents $r^{2}(\times 100)$; black cells $r^{2}=1$; white cells $r^{2}=0$. Each cell is colored in a graduated manner according to the strength of LD

Statistical analysis

Pairwise LD in SNPs was estimated as $r^{2}$ (Hill and Robertson 1968). A $2 \times 2$ contingency $\chi^{2}$ test of independence was performed to evaluate the significance of an association between allele frequency and disease status. Haplotype inference and a case-control association study were performed using SNPAlyze ver. 4.1 program (DYNACOM, Mobara, Japan). The effects of genotypes on $\log _{10}$-transformed total serum $\mathrm{IgE}$ levels were evaluated using analysis of variance (ANOVA). Statistical analysis was performed with SPSS software (ver. 15.0 J; SPSS Japan, Tokyo, Japan). In SNP association studies, corrected $P$ $\left(P_{\text {cor }}\right)$ values were calculated by multiplying the number of SNPs tested in this study (15). In haplotype association studies, $P_{\text {cor }}$ values were calculated by multiplying the total number of haplotypes tested in the entire gene (27). Association of an SNP or haplotype with the disease was judged as significant if $P_{\text {cor }}$ for the test of allele/haplotype frequency was $<0.05$. 
Table 3 Primers for genotyping single nucleotide polymorphisms (SNPs) in the $C 3$ gene

\begin{tabular}{|c|c|}
\hline SNP genotyped & Sequence \\
\hline \multicolumn{2}{|l|}{ SNP1 } \\
\hline F: T allele & 5'-GGCATAAACAAGGGTTAAAATGT \\
\hline F: C allele & 5'-GGCATAAACAAGGGTTAAAATGC \\
\hline R: common & 5'-GCTCACAAACGCCTATGA \\
\hline TaqMan probe & 5'-TGAAATAGATAAGTTGCTGCCACCCG \\
\hline \multicolumn{2}{|l|}{ SNP2 } \\
\hline F: C allele & 5'-GCCTGGCCAACATGGCGAACC \\
\hline F: T allele & 5'-GCCTGGCCAACATGGCGAAGT \\
\hline $\mathrm{R}$ : common & 5'-TGCCTCCTGGGTTCAAGTGATTCTC \\
\hline TaqMan probe & 5'-TAGTGGCGCATGCCTGTGATCCCAGCTCT \\
\hline First PCR F: & 5'-TTCCAAAGAGTGTGTCGCAA \\
\hline First PCR R: & 5'-CCTGCTTCATAGAGTTGTCGT \\
\hline \multicolumn{2}{|l|}{ SNP3 } \\
\hline F: A allele & 5'-TTTGGCAATATCTAGCAAGATTACCTA \\
\hline F: G allele & 5'-TTTGGCAATATCTAGCAAGATTACCTG \\
\hline R: common & 5'-CCTTACCACCTGCTTCATAGAGTTG \\
\hline TaqMan probe & 5'-TGACCCAACATATTTCCTTTCATTGCAACG \\
\hline \multicolumn{2}{|l|}{ SNP4 } \\
\hline F: C allele & 5'-CCTGTAACCTGTAAGAATGAGAC \\
\hline F: A allele & 5'-CCTGTAACCTGTAAGAATGAGTA \\
\hline R: common & 5'-CAAAGTGCTGGTGTGAACTACTG \\
\hline TaqMan probe & 5'-TAGTATGTGCTATGTGCTGTCC \\
\hline \multicolumn{2}{|l|}{ SNP5 } \\
\hline R: A allele & 5'-GCCTGCCCATTATTCTTGGTCCT \\
\hline R: G allele & 5'-GCCTGCCCATTATTCTTGGTCAC \\
\hline F: common & 5'-CCTTGTGAGCTCTTCTTTTTGAGTTC \\
\hline \multicolumn{2}{|l|}{ SNP6 } \\
\hline R: G allele & 5'-CACCCCGTCCAGCAGTACCTAC \\
\hline R: A allele & 5'-CACCCCGTCCAGCAGTACCTAT \\
\hline F: common & 5'-AACAGAGGATTTCCCTGCCTGAA \\
\hline TaqMan probe & 5'-CCCTCAAGCGCATTCCG \\
\hline \multicolumn{2}{|l|}{ SNP7 } \\
\hline F: A allele & 5'-AACAGAGGATTTCCCTGCCTGTA \\
\hline F: G allele & 5'-AACAGAGGATTTCCCTGCCTGGG \\
\hline R: common & 5'-CACCCCGTCCAGCAGTACCTTC \\
\hline TaqMan probe & 5'-CCCTCAAGCGCATTCCG \\
\hline \multicolumn{2}{|l|}{ SNP8 } \\
\hline F: G allele & 5'-TGCTGAATAAGAAGAACAAACTGAGG \\
\hline F: A allele & 5'-TGCTGAATAAGAAGAACAAACTGAGA \\
\hline R: common & 5'-TGCCTCCGCCTCTTCTCA \\
\hline \multicolumn{2}{|l|}{ SNP9 } \\
\hline F: G allele & 5'-TAGGGACGAAGATGGAGATGTG \\
\hline $\mathrm{G}$ allele & 5'-TAGGGACGAAGATGGAGATGAG \\
\hline F: A allele & 5'-TAGGGACGAAGATGGAGATGTA \\
\hline A allele & $5^{\prime}$-TAGGGACGAAGATGGAGATGAA \\
\hline R: common & 5'-СТTATCTCCATTTCСССТCTGATTC \\
\hline \multicolumn{2}{|l|}{ SNP10 } \\
\hline R: G allele & 5'-TGATTCCATCTGCATTCCCAAC \\
\hline R: A allele & 5'-TGATTCCATCTGCATTCCCAAT \\
\hline F: common & 5'-TTTCCGGAGTAGGGACGAAGA \\
\hline
\end{tabular}

Table 3 continued

\begin{tabular}{|c|c|}
\hline SNP genotyped & Sequence \\
\hline \multicolumn{2}{|l|}{ SNP11 } \\
\hline F: A allele & 5'-AGGGTCACTGGGAAAATTAGACATA \\
\hline F: G allele & 5'-AGGGTCACTGGGAAAATTAGACAGG \\
\hline R: common & 5'-ATGGGCCAAAGGAATTACACAAT \\
\hline \multicolumn{2}{|l|}{ SNP12 } \\
\hline F: A allele & 5'-ACTCCCCGACCTTGACACTAA \\
\hline F: C allele & 5'-ACTCCCCGACCTTGACACTAC \\
\hline R: common & 5'-CCTGCATTACTGTGACCTCGAA \\
\hline TaqMan probe & 5'-CCCGAGCAGGGATCTGTGTGGCA \\
\hline \multicolumn{2}{|l|}{ SNP13 } \\
\hline F: C allele & 5'-GGAAGTGGAAGTCAAGGCTGGC \\
\hline F: T allele & 5'-GGAAGTGGAAGTCAAGGCTGGT \\
\hline R: common & 5'-GGGTGCCCCAAGCACTCA \\
\hline TaqMan probe & 5'-CCATCATTTCATCAGTGACGGTGTCAGGAA \\
\hline \multicolumn{2}{|l|}{ SNP14 } \\
\hline $\mathrm{R}: \mathrm{T}$ allele & 5'-GAATGAGATGGAATTTGGCTCGA \\
\hline $\mathrm{R}: \mathrm{C}$ allele & 5'-GAATGAGATGGAATTTGGCTCTG \\
\hline F: common & 5'-CAAGTCCCGGACACCGAGTCT \\
\hline \multicolumn{2}{|l|}{ SNP15 } \\
\hline $\mathrm{R}: \mathrm{C}$ allele & 5'-CAGCGAGCTGAGGTCGGG \\
\hline $\mathrm{R}: \mathrm{T}$ allele & 5'-CAGCGAGCTGAGGTCGTA \\
\hline F: common & 5'-CATCTGTGATCTGTTTTCCCTCTTTTAC \\
\hline \multicolumn{2}{|l|}{ SNP16 } \\
\hline $\mathrm{R}: \mathrm{C}$ allele & 5'-GAGTGTCTCACTTAATAGTCAACGATG \\
\hline R: G allele & 5'-GAGTGTCTCACTTAATAGTCAACGATC \\
\hline F: common & 5'-TGGTCAGGCTGGTCTTGAACTC \\
\hline \multicolumn{2}{|l|}{ SNP17 } \\
\hline F: G allele & 5'-CTGCCAAAGTTTTGGGATCACTG \\
\hline F: A allele & 5'-CTGCCAAAGTTTTGGGATCACTA \\
\hline R: common & 5'-CCACACCCGGCCATTTCC \\
\hline \multicolumn{2}{|l|}{ SNP18 } \\
\hline $\mathrm{R}: \mathrm{C}$ allele & 5'-AATGCCAGAAGTGAACTTCAAAGTG \\
\hline R: G allele & 5'-AATGCCAGAAGTGAACTTCAAAGTC \\
\hline F: common & 5'-CAGCAGGGTCAACATCACCATA \\
\hline \multicolumn{2}{|l|}{ SNP19 } \\
\hline F: T allele & 5'-GGCTGCCTGTATTCTTGCCTAT \\
\hline F: delT allele & 5'-GGCTGCCTGTATTCTTGCCTCG \\
\hline R: common & 5'-TGGATTCAAATTCCAGCTCTAAATAAC \\
\hline \multicolumn{2}{|l|}{ SNP20 } \\
\hline F: A allele & 5'-ATTCCAAGCATGAGCCACGA \\
\hline F: G allele & 5'-ATTCCAAGCATGAGCCACGG \\
\hline R: common & 5'-GGAGAGGAGAAAGCCCAAATCA \\
\hline \multicolumn{2}{|l|}{ SNP21 } \\
\hline R: A allele & 5'-GATGGAGAGAAAATAACAGAAGAGTT \\
\hline $\mathrm{R}: \mathrm{C}$ allele & 5'-GATGGAGAGAAAATAACAGAAGAGCG \\
\hline F: common & 5'-ATGTTGCTCAAGTTGGTCTCAAACT \\
\hline \multicolumn{2}{|l|}{ SNP22 } \\
\hline R: A allele & 5'-GGCCTCCCTCCAAAGACCCT \\
\hline R: G allele & 5'-GGCCTCCCTCCAAAGACCTC \\
\hline F: common & 5'-CGTGTCCCAGGAATCTATGAATTT \\
\hline
\end{tabular}


Table 3 continued

\begin{tabular}{ll}
\hline SNP genotyped & Sequence \\
\hline SNP23 & \\
R: G allele & 5'-ACCGGGTACAGCTTTCCTCTAC \\
R: A allele & 5'-ACCGGGTACAGCTTTCCTCTTT \\
F: common & 5'-GGCTTCTGTGAGTTGAGAGTCTAAGAGA \\
SNP24 & \\
F: T allele & 5'-CATGGCCATGAGGCTACAGTATAT \\
F: C allele & 5'-CATGGCCATGAGGCTACAGTATAC \\
R: common & 5'-CCCATGTCACCATCCACACA \\
SNP25 & \\
F: T allele & 5'-ACACTTGGGTGGAGCACTGGCAT \\
F: C allele & 5'-ACACTTGGGTGGAGCACTGGCTC \\
R: common & 5'-GGTCCTGGCATTGTTTCTGGTTCTC \\
TaqMan probe & 5'-AGGAGGACGAATGCCAAGACG \\
SNP26 & \\
R: T allele & 5'-GGTGAGAATGTGGGCAAGAAGA \\
R: G allele & 5'-GGTGAGAATGTGGGCAAGAAGC \\
F: common & 5'-ACCTACATCCTCTCCGGTGAGTGT
\end{tabular}

$P C R$ polymerase chain reaction, $F$ forward primer, $R$ reverse primer. All TaqMan probes were labeled with 6-carboxyfluorescein (FAM, reporter dye) at the $5^{\prime}$ end and 6-carboxy-tetramethyl-rhodamine (TAMRA, quenching dye) at $3^{\prime}$ end

\section{Results}

Polymorphisms in the $C 3$ gene

We selected and characterized 26 SNPs from the $C 3$ gene to investigate mainly genetic variations of the promoter region, SNPs forming a haplotype that showed significant association with BA in African Caribbean families, and the $3^{\prime}$ end region where a SNP showed significant association with BA in our previous study (Table 2). The location of the SNPs and LD map is shown in Fig. 1. If an LD block was defined by the solid spine of LD, out of the 26 SNPs investigated, 24 composed four LD blocks. SNP10 showed $r^{2}$ values $<0.033$ to any other SNPs investigated in the current study and excluded from any LD block under this definition. Although SNP16 showed moderate LD to SNP15 $\left(r^{2}=0.71\right)$ and SNP11 $\left(r^{2}=0.60\right)$, it did not belong to LD block 3, where SNP15 and SNP11 are located. This is because of the characteristic of the "solid spin of LD" definition. When SNP12 and SNP14, both of which showed very low $r^{2}(<0.01)$ to SNP16, were omitted from LD block 3, SNP16 was found to be included in LD block 3. As tag SNPs, four SNPs each were selected in LD blocks from 1 to 3 and three SNPs in LD block 4 (Fig. 1).

Association study of childhood and adult BA

We genotyped 15 tag SNPs in 304 childhood BA, 371 adult BA, 333 child controls, and 550 adult controls (Table 1).
All loci were in Hardy-Weinberg equilibrium in the control groups. The genotype and allele frequencies of each SNP in the patient and control groups are shown in Table 4. Results of association tests for allele frequency between the patient and control groups are also shown. Allelic frequency of SNP24 was significantly different between adult BA and adult controls $(P=0.002)$. The $P$ value for the difference remained significant $\left(P_{\text {cor }}=0.030\right)$ after correction for the number of SNPs tested (15). In a recessive model, the odds ratio (OR) and its 95\% confidence interval $(95 \% \mathrm{CI})$ range for this SNP were 1.55 and 1.15-2.09, respectively. In a dominant model, the OR and $95 \%$ CI range were 1.37 and $1.01-1.88$, respectively. The difference in the allele frequency of SNP24 between all BA and all control showed a similar tendency. However, the $P$ value was not significant $\left(P=0.004, P_{\text {cor }}=0.060\right)$. None of the other SNPs showed a significant association with either childhood or adult BA.

The frequencies of haplotypes consisting of tag SNPs in four LD blocks are shown in Table 5. A significant difference was observed in LD block 4 (Table 5). In LD block 4 containing exons 24-41, the frequency of the major haplotype CCC in adult BA $(54.1 \%)$ was significantly higher than that in controls $(46.4 \%)\left(P=0.0014, P_{\text {cor }}=\right.$ 0.038 ). The frequencies of C alleles of SNP18, SNP19, and SNP24 were higher in adult BA than in adult controls. These increased frequencies were straightforwardly associated with the increased frequency of the CCC haplotype. The frequency of this haplotype in childhood BA $(51.0 \%)$ was not significantly higher than that in adult controls (48.6\%) $\left(P_{\text {cor }}>1.0\right)$. The OR of the CCC haplotype of LD block 4 was about 1.4 for both childhood and adult BA (Table 6). In LD block 2 containing at least exons 3-14, the frequency of the GGAG haplotype in childhood BA $(5.6 \%)$ was higher than that in child controls $(2.5 \%)(P=$ 0.0044). This difference, however, did not reach a genewide significance $\left(P_{\text {cor }}=0.12\right)$. In LD blocks 1 and 3, there was no haplotype showing any difference in frequency between patients and controls. LD block 1 contains the promoter region of the $C 3$ gene; therefore, it is not likely that genetic variations of the promoter region have significant effect on susceptibility to BA in the Japanese population.

Barnes et al. reported that a 3-SNP haplotype consisting of the SNPs identical to SNP14, SNP15, and SNP16 showed significant association with $\mathrm{BA}, \log$ (total $\mathrm{IgE}$ ) and $\log ($ IL-13)/log (IFN- $\gamma)$ in the Afro-Caribbean families (Barnes et al. 2006). To assess the reproducibility of their results, we investigated whether this 3-SNP haplotype shows association with either childhood BA, adult BA, or $\log$ (total IgE) in our samples. We found that this haplotype showed no significant association with any of these phenotypes. 


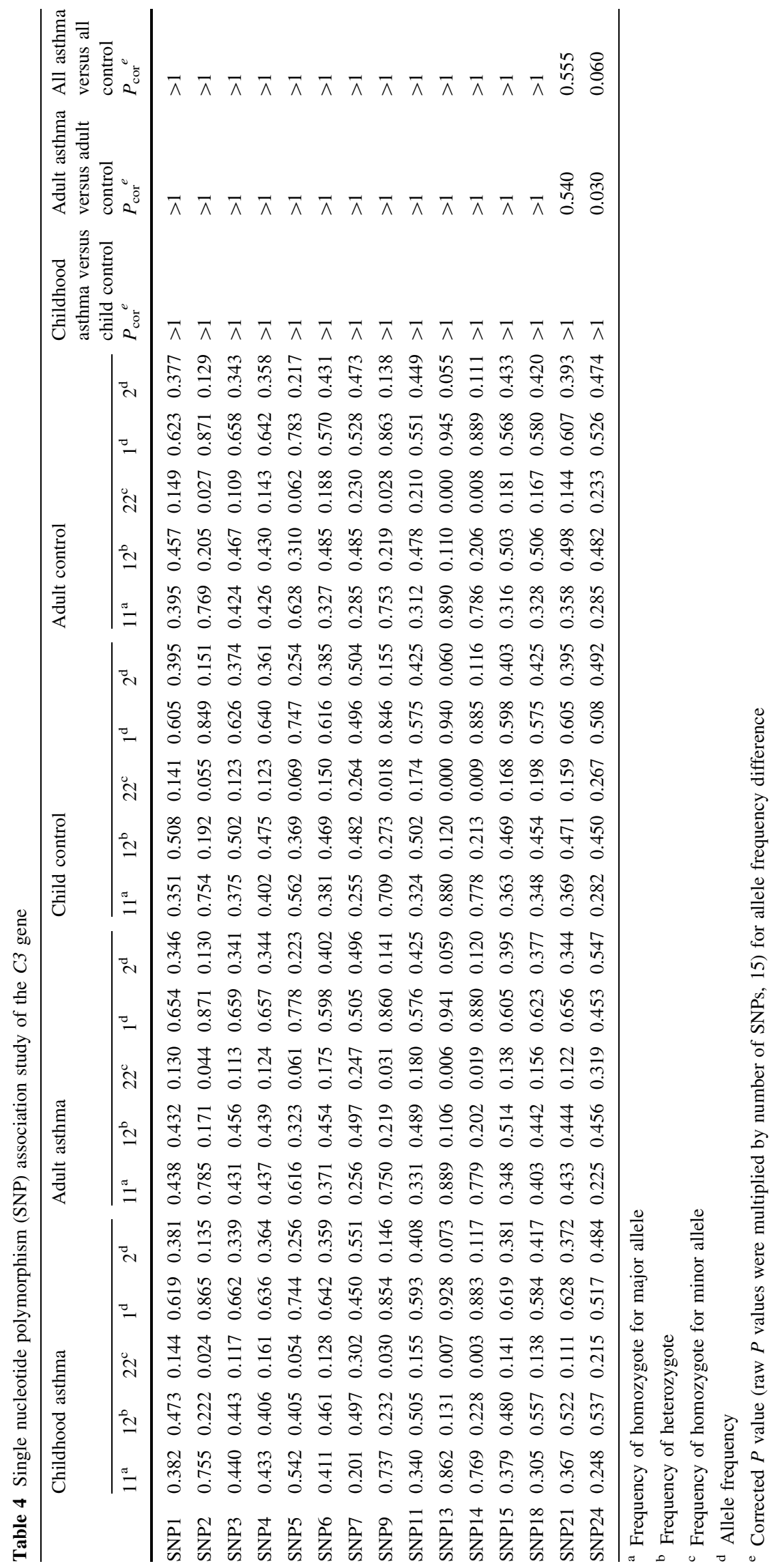


Table 5 Haplotype association study of the $C 3$ gene
${ }^{a}$ Corrected $P$ value (raw $P$ values were multiplied by the number of haplotypes tested, 27) for haplotype frequency difference

b This haplotype is consisted of SNPs $1,2,3$, and 4

c This haplotype is consisted of SNPs 5, 6, 7, and 9

d This haplotype is consisted of SNPs $11,13,14$, and 15

e This haplotype is consisted of SNPs 18, 21, and 24

\begin{tabular}{|c|c|c|c|c|c|c|c|}
\hline \multirow[t]{2}{*}{ Haplotype } & \multicolumn{4}{|l|}{ Frequency } & \multicolumn{3}{|l|}{$P_{\text {cor }}^{\mathrm{a}}$} \\
\hline & $\begin{array}{l}\text { Childhood } \\
\text { asthma }\end{array}$ & $\begin{array}{l}\text { Adult } \\
\text { asthma }\end{array}$ & $\begin{array}{l}\text { Child } \\
\text { control }\end{array}$ & $\begin{array}{l}\text { Adult } \\
\text { control }\end{array}$ & $\begin{array}{l}\text { Childhood asthma } \\
\text { vs. control }\end{array}$ & $\begin{array}{l}\text { Adult asthma } \\
\text { vs. control }\end{array}$ & $\begin{array}{l}\text { All-asthma } \\
\text { vs. control }\end{array}$ \\
\hline \multicolumn{8}{|l|}{ Block $1^{\mathrm{b}}$} \\
\hline TCAA & 0.441 & 0.483 & 0.436 & 0.467 & $>1$ & $>1$ & $>1$ \\
\hline CCGC & 0.295 & 0.263 & 0.279 & 0.280 & $>1$ & $>1$ & $>1$ \\
\hline TTAA & 0.129 & 0.108 & 0.121 & 0.103 & $>1$ & $>1$ & $>1$ \\
\hline CCAA & 0.051 & 0.043 & 0.041 & 0.042 & $>1$ & $>1$ & $>1$ \\
\hline TCGC & 0.032 & 0.051 & 0.040 & 0.021 & $>1$ & 0.222 & $>1$ \\
\hline CCGA & 0.009 & 0.014 & 0.032 & 0.020 & 0.192 & $>1$ & 0.297 \\
\hline CCAC & 0.019 & 0.010 & 0.019 & 0.016 & $>1$ & $>1$ & $>1$ \\
\hline TCAC & 0.018 & 0.009 & 0.004 & 0.017 & 0.324 & $>1$ & $>1$ \\
\hline Others & 0.006 & 0.022 & 0.029 & 0.027 & & & \\
\hline \multicolumn{8}{|l|}{ Block $2^{\mathrm{c}}$} \\
\hline AAGG & 0.322 & 0.361 & 0.333 & 0.403 & $>1$ & $>1$ & $>1$ \\
\hline AGAG & 0.337 & 0.301 & 0.310 & 0.291 & $>1$ & $>1$ & $>1$ \\
\hline GGAA & 0.124 & 0.110 & 0.141 & 0.115 & $>1$ & $>1$ & $>1$ \\
\hline AGGG & 0.058 & 0.067 & 0.072 & 0.063 & $>1$ & $>1$ & $>1$ \\
\hline GGGG & 0.049 & 0.055 & 0.053 & 0.051 & $>1$ & $>1$ & $>1$ \\
\hline GGAG & 0.056 & 0.042 & 0.025 & 0.037 & 0.121 & $>1$ & 0.729 \\
\hline AAAG & 0.016 & 0.018 & 0.015 & 0.015 & $>1$ & $>1$ & $>1$ \\
\hline AGAA & 0.014 & 0.024 & 0.013 & 0.010 & $>1$ & 0.567 & $>1$ \\
\hline GAGG & 0.019 & 0.015 & 0.036 & 0.009 & $>1$ & $>1$ & $>1$ \\
\hline Others & 0.006 & 0.006 & 0.002 & 0.005 & & & \\
\hline \multicolumn{8}{|l|}{ Block $3^{\mathrm{d}}$} \\
\hline ACCC & 0.460 & 0.446 & 0.445 & 0.424 & $>1$ & $>1$ & $>1$ \\
\hline GCCT & 0.365 & 0.382 & 0.384 & 0.418 & $>1$ & $>1$ & $>1$ \\
\hline ATTC & 0.066 & 0.058 & 0.055 & 0.054 & $>1$ & $>1$ & $>1$ \\
\hline ACTC & 0.049 & 0.059 & 0.057 & 0.055 & $>1$ & $>1$ & $>1$ \\
\hline GCCC & 0.041 & 0.041 & 0.038 & 0.034 & $>1$ & $>1$ & $>1$ \\
\hline ACCT & 0.013 & 0.012 & 0.014 & 0.013 & $>1$ & $>1$ & $>1$ \\
\hline Others & 0.006 & 0.002 & 0.006 & 0.003 & & & \\
\hline \multicolumn{8}{|l|}{ Block $4^{\mathrm{e}}$} \\
\hline $\mathrm{CCC}$ & 0.510 & 0.541 & 0.486 & 0.464 & $>1$ & 0.038 & 0.079 \\
\hline GAT & 0.365 & 0.340 & 0.387 & 0.375 & $>1$ & $>1$ & $>1$ \\
\hline $\mathrm{CCT}$ & 0.066 & 0.078 & 0.081 & 0.098 & $>1$ & $>1$ & $>19$ \\
\hline GCT & 0.053 & 0.033 & 0.038 & 0.044 & $>1$ & $>1$ & $>1$ \\
\hline Others & 0.007 & 0.011 & 0.008 & 0.019 & & & \\
\hline
\end{tabular}

Table 6 Odds ratio (OR) and its 95\% confidence interval (CI) of the CCC haplotype for bronchial asthma (BA)

\begin{tabular}{|c|c|c|c|c|c|}
\hline & \multicolumn{5}{|c|}{ Diplotype frequency $(\%)$} \\
\hline & \multicolumn{2}{|l|}{ Case } & \multicolumn{3}{|l|}{ Control } \\
\hline & $\begin{array}{l}\mathrm{CCC} / \mathrm{CCC} \text { and } \\
\mathrm{CCC} / \text { other }\end{array}$ & Other/other & $\mathrm{CCC} / \mathrm{CCC}$ and $\mathrm{CCC} /$ other & Other/other & $\begin{array}{l}\text { Odds ratio } \\
(95 \% \mathrm{CI})\end{array}$ \\
\hline Childhood BA & 77.8 & 22.2 & 71.2 & 28.8 & $1.42(0.99-2.04)$ \\
\hline Adult BA & 76.9 & 23.1 & 71.0 & 29.0 & $1.36(1.00-1.86)$ \\
\hline All BA & 77.3 & 22.7 & 71.1 & 28.9 & $1.39(1.10-1.75)$ \\
\hline
\end{tabular}

Diplotype of each individual was inferred with SNPAlyze ver. 4.1. OR and its (95\% CI) were determined with SPSS ver. 15.0 
Effect of genetic variations of the $C 3$ gene on serum total $\mathrm{IgE}$ level

To examine the effect of genetic variations of the $C 3$ gene on serum IgE level, 15 tag SNPs and the CCC haplotype were analyzed by analysis of variance (ANOVA) for logtransformed serum total IgE values (Table 7). $P$ values $<0.05$ were observed in SNP14 in adult BA patients $(P=$ $0.042)$ and in SNP13 $(P=0.018)$ and SNP18 $(0.041)$ in child controls. If we want to maintain type 1 error at 0.05 in each patient/control group, a $P$ value $<0.0031(0.05 / 16)$ should be considered as significant. Thus, we deduced that these SNPs did not significantly affect serum total IgE level. The genotype of SNP24 and the CCC haplotype, both of which showed an association with adult BA, were not significantly associated with the IgE level.

Table 7 Effect of single nucleotide polymorphisms (SNPs) and haplotypes of the $C 3$ gene on $\log _{10}$-transformed total immunoglobulin $\mathrm{E}(\mathrm{IgE})$

\begin{tabular}{|c|c|c|c|}
\hline \multirow[t]{2}{*}{ Locus } & \multicolumn{3}{|c|}{$P$ value in ANOVA test ${ }^{\mathrm{a}}$} \\
\hline & $\begin{array}{l}\text { Childhood } \\
\text { asthma }\end{array}$ & $\begin{array}{l}\text { Adult } \\
\text { asthma }\end{array}$ & $\begin{array}{l}\text { Child } \\
\text { control }\end{array}$ \\
\hline \multicolumn{4}{|l|}{ Block 1} \\
\hline SNP1 & 0.347 & 0.242 & 0.250 \\
\hline SNP2 & 0.657 & 0.960 & 0.320 \\
\hline SNP3 & 0.276 & 0.051 & 0.720 \\
\hline SNP4 & 0.329 & 0.058 & 0.182 \\
\hline \multicolumn{4}{|l|}{ Block 2} \\
\hline SNP5 & 0.537 & 0.794 & 0.119 \\
\hline SNP6 & 0.860 & 0.533 & 0.805 \\
\hline SNP7 & 0.952 & 0.556 & 0.497 \\
\hline SNP9 & 0.368 & 0.795 & 0.270 \\
\hline \multicolumn{4}{|l|}{ Block 3} \\
\hline SNP11 & 0.463 & 0.678 & 0.937 \\
\hline SNP13 & 0.917 & 0.100 & 0.018 \\
\hline SNP14 & 0.485 & 0.042 & 0.261 \\
\hline SNP15 & 0.486 & 0.816 & 0.688 \\
\hline \multicolumn{4}{|l|}{ Block 4} \\
\hline SNP18 & 0.197 & 0.890 & 0.041 \\
\hline SNP21 & 0.065 & 0.280 & 0.097 \\
\hline SNP24 & 0.356 & 0.661 & 0.526 \\
\hline CCC haplotype & 0.175 & 0.586 & 0.505 \\
\hline
\end{tabular}

${ }^{a}$ Significance of difference in the mean of $\log _{10}$ (total $\operatorname{IgE}$ ) among individuals with different genotypes (major allele homozygote, heterozygote, minor allele homozygote) was tested with analysis of variance (ANOVA). Three groups (childhood asthma, adult asthma, and child control) were evaluated separately. Serum IgE level was not determined in the adult control group

\section{Discussion}

In this study, we investigated the association of SNPs in the C3 gene with childhood and adult BA. We observed a significant association of SNP24 and the CCC haplotype in LD block 4 with adult BA. As the CCC haplotype was discriminated from other major haplotypes with a frequency of $>1 \%$ by the SNP24 allele $(\mathrm{C} / \mathrm{T})$, this haplotype association may just be a reflection of the association of SNP24. There was no significant difference in genotype frequency of SNP24 between the adult control group and the child control group, suggesting that the significant association observed in the adult patients-control comparison was not due to skewed genotype frequency of adult controls but to changes in adult BA. The frequency of the T/T genotype in childhood BA was decreased (from 0.282 to 0.248 ), as in adult BA. However, the change in allele frequency in childhood BA compared with that in child controls was small (T allele: 0.517 vs. 0.508 ). This SNP (or that with strong LD to this SNP) may not be a risk-modifying variation for childhood BA. Although it was not significant at the gene-wide level, we observed a tendency of the frequency of the GGAG haplotype of LD block 2 to show a difference between childhood BA and child controls $(P=$ $\left.0.0045, P_{\text {cor }}=0.121\right)$. To determine and definitively conclude whether this LD block confers risk for childhood BA, an association study with more childhood samples and functional analyses of this region will be necessary.

LD block 4 is about $20 \mathrm{~kb}$ long and contains exon 41 coding the $\mathrm{C}$-terminal end of the $\mathrm{C} 3$ protein and $3^{\prime}$ untranslated region as well as upstream 17 exons and introns. Because we could not find SNPs that change the amino acid sequences in exons in this LD block, functional variation(s) in this region should be those affecting either expression of the gene, ribonucleic acid (RNA) splicing, or RNA stability. To the best of our knowledge, there is as yet no study investigating elements affecting gene expression in this region of the $C 3$ gene. Currently, we do not have sufficient data to discuss the underlying mechanisms of the association between the LD block and adult BA. Further genetic and functional analyses of the LD blocks are necessary to pinpoint genetic variation(s) responsible for differences in susceptibility to BA.

It is possible that some of the control subjects involved in this study will develop asthma. Judging from the prevalence of the asthma in Japan, the chance of developing the disease is expected to be several percent. If we exclude atopic subjects from the control group, the chance may be reduced but not completely eliminated. This issue cannot be thoroughly controlled in a case-control study. The fact that our control group contained presymptomatic BA patients reduces the statistical power to detect an association between genotypes and the disease. We must be aware of this issue 
when obtaining negative results. However, the main result (i.e., the significant association of the haplotype with the disease) cannot be changed by this issue. If we could eliminate presymptomatic BA patients, estimated ORs would be higher than the values we presented in this study.

We also investigated whether genetic variations of the $C 3$ gene affect total serum IgE level using childhood and adult BA patients and child controls. The IgE level was not significantly affected by any SNPs or haplotypes, including those showing a significant association with adult BA. This was true with mite-specific IgE level (data not shown). These results suggest that genetic variations of LD block 4 showing susceptibility to BA have a slight effect on sensitization to allergens but are more relevant to the effector phase of allergic inflammation. The roles of anaphylatoxins in the pathogenesis of BA can be divided into two phases: sensitization to allergens and effector phase of allergic BA (Kohl and Wills-Karp 2007). Several roles of C5a signaling at the interface between dendritic cells and $\mathrm{T}$ cells are evident, but those of $\mathrm{C} 3 \mathrm{a}$ remain unclear. In a $\mathrm{C} 3 \mathrm{aR}$ knockout experiment, different Th2 cytokine production responses were reported in various strains of mice (C57BL/6 and BALB/c) (Drouin et al. 2002; Humbles et al. 2000), suggesting that the effect of $\mathrm{C} 3 \mathrm{a}$ is influenced by genetic background. As observed in mice, a difference in genetic background may explain the fact that association of the haplotype consisting of SNP14, SNP15, and SNP16 with total IgE level observed in Afro-Caribbean families was not confirmed in the Japanese population. Discrepancy between our results and those of Barnes et al. may also be due to a difference in the environmental factors of the two study populations. There are a number of studies showing that the effects of genetic variation $(-159 \mathrm{C} / \mathrm{T})$ of the $\mathrm{CD} 14$ gene on allergic sensitization and BA risk differ greatly due to environmental factors such as mite or lipopolysacharide concentration in dust (Ober et al. 2000; Simpson et al. 2006; Vercelli 2003; Zambelli-Weiner et al. 2005). It may be possible that $C 3$ gene variations also show this type of geneenvironmental interaction and cause discrepant results in studies with different populations.

In summary, our results suggest that the LD block containing exons 24-41 of the $C 3$ gene confer susceptibility to adult BA in the Japanese population. Because this region showed a slight effect on serum IgE level in both BA patients and normal individuals, this region may be involved in the effector phase of allergic inflammation. The effect of variations of the $C 3$ gene on allergic sensitization and BA susceptibility may differ according to genetic background and environmental factors.

Acknowledgments We thank all patients and their families, volunteers who served as controls, and all staff members of hospitals involved in this study. We are also grateful for the excellent technical assistance of Kazuko Hatori, Mieko Yoshida, and Yoshiko Hotta. This work was supported by Grants-in-Aid for Scientific Research from the Ministry of Education, Culture, Sports, Science, and Technology, Japan, and grants from the Ministry of Health, Labor, and Welfare, Japan.

\section{References}

Asher MI, Keil U, Anderson HR, Beasley R, Crane J, Martinez F, Mitchell EA, Pearce N, Sibbald B, Stewart AW et al (1995) International Study of Asthma and Allergies in Childhood (ISAAC): rationale and methods. Eur Respir J 8:483-491

Barnes KC, Marsh DG (1998) The genetics and complexity of allergy and asthma. Immunol Today 19:325-332

Barnes KC, Grant AV, Baltadzhieva D, Zhang S, Berg T, Shao L, Zambelli-Weiner A, Anderson W, Nelsen A, Pillai S, Yarnall DP, Dienger K, Ingersoll RG, Scott AF, Fallin MD, Mathias RA, Beaty TH, Garcia JG, Wills-Karp M (2006) Variants in the gene encoding C3 are associated with asthma and related phenotypes among African Caribbean families. Genes Immun 7:27-35

Barrett JC, Fry B, Maller J, Daly MJ (2005) Haploview: analysis and visualization of LD and haplotype maps. Bioinformatics 21:263265

Barrington R, Zhang M, Fischer M, Carroll MC (2001) The role of complement in inflammation and adaptive immunity. Immunol Rev 180:5-15

Bautsch W, Hoymann HG, Zhang Q, Meier-Wiedenbach I, Raschke U, Ames RS, Sohns B, Flemme N, Meyer zu Vilsendorf A, Grove M, Klos A, Kohl J (2000) Cutting edge: guinea pigs with a natural C3a-receptor defect exhibit decreased bronchoconstriction in allergic airway disease: evidence for an involvement of the $\mathrm{C} 3 \mathrm{a}$ anaphylatoxin in the pathogenesis of asthma. J Immunol 165:5401-5405

Blumenthal MN, Ober C, Beaty TH, Bleecker ER, Langefeld CD, King RA, Lester L, Cox N, Barnes K, Togias A, Mathias R, Meyers DA, Oetting W, Rich SS (2004) Genome scan for loci linked to mite sensitivity: the Collaborative Study on the Genetics of Asthma (CSGA). Genes Immun 5:226-231

Drouin SM, Corry DB, Kildsgaard J, Wetsel RA (2001) Cutting edge: the absence of $\mathrm{C} 3$ demonstrates a role for complement in Th2 effector functions in a murine model of pulmonary allergy. J Immunol 167:4141-4145

Drouin SM, Corry DB, Hollman TJ, Kildsgaard J, Wetsel RA (2002) Absence of the complement anaphylatoxin C3a receptor suppresses Th2 effector functions in a murine model of pulmonary allergy. J Immunol 169:5926-5933

Ferris BG (1978) Epidemiology Standardization Project (American Thoracic Society). Am Rev Respir Dis 118:1-120

Fujii K, Matsubara Y, Akanuma J, Takahashi K, Kure S, Suzuki Y, Imaizumi M, Iinuma $\mathrm{K}$, Sakatsume $\mathrm{O}$, Rinaldo $\mathrm{P}$, Narisawa $\mathrm{K}$ (2000) Mutation detection by TaqMan-allele specific amplification: application to molecular diagnosis of glycogen storage disease type Ia and medium-chain acyl-CoA dehydrogenase deficiency. Hum Mutat 15:189-196

Hasegawa K, Tamari M, Shao C, Shimizu M, Takahashi N, Mao XQ, Yamasaki A, Kamada F, Doi S, Fujiwara H, Miyatake A, Fujita K, Tamura G, Matsubara Y, Shirakawa T, Suzuki Y (2004) Variations in the $\mathrm{C} 3, \mathrm{C} 3 \mathrm{a}$ receptor, and $\mathrm{C} 5$ genes affect susceptibility to bronchial asthma. Hum Genet 115:295-301

Hill WG, Robertson A (1968) Linkage disequilibrium in finite populations. Theor Appl Genet 38:226-231

Humbles AA, Lu B, Nilsson CA, Lilly C, Israel E, Fujiwara Y, Gerard NP, Gerard C (2000) A role for the C3a anaphylatoxin receptor in the effector phase of asthma. Nature 406:998-1001 
Kawamoto S, Yalcindag A, Laouini D, Brodeur S, Bryce P, Lu B, Humbles AA, Oettgen H, Gerard C, Geha RS (2004) The anaphylatoxin $\mathrm{C} 3 \mathrm{a}$ downregulates the $\mathrm{Th} 2$ response to epicutaneously introduced antigen. J Clin Invest 114:399-407

Kohl J (2001) Anaphylatoxins and infectious and non-infectious inflammatory diseases. Mol Immunol 38:175-187

Kohl J, Wills-Karp M (2007) A dual role for complement in allergic asthma. Curr Opin Pharmacol 7:283-289

Krug N, Tschernig T, Erpenbeck VJ, Hohlfeld JM, Kohl J (2001) Complement factors $\mathrm{C} 3 \mathrm{a}$ and $\mathrm{C} 5 \mathrm{a}$ are increased in bronchoalveolar lavage fluid after segmental allergen provocation in subjects with asthma. Am J Respir Crit Care Med 164:1841-1843

Lee YA, Wahn U, Kehrt R, Tarani L, Businco L, Gustafsson D, Andersson F, Oranje AP, Wolkertstorfer A, Berg AV, Hoffmann U, Kuster W, Wienker T, Ruschendorf F, Reis A (2000) A major susceptibility locus for atopic dermatitis maps to chromosome $3 q 21$. Nat Genet 26:470-473

Muller-Eberhard HJ (1988) Molecular organization and function of the complement system. Annu Rev Biochem 57:321-347

Nakano Y, Morita S, Kawamoto A, Suda T, Chida K, Nakamura H (2003) Elevated complement C3a in plasma from patients with severe acute asthma. J Allergy Clin Immunol 112:525-530

Nakashima K, Hirota T, Obara K, Shimizu M, Jodo A, Kameda M, Doi S, Fujita K, Shirakawa T, Enomoto T, Kishi F, Yoshihara S, Matsumoto K, Saito H, Suzuki Y, Nakamura Y, Tamari M (2006) An association study of asthma and related phenotypes with polymorphisms in negative regulator molecules of the TLR signaling pathway. J Hum Genet 51:284-291
Ober C, Tsalenko A, Parry R, Cox NJ (2000) A second-generation genomewide screen for asthma-susceptibility alleles in a founder population. Am J Hum Genet 67:1154-1162

Simpson A, John SL, Jury F, Niven R, Woodcock A, Ollier WE, Custovic A (2006) Endotoxin exposure, CD14, and allergic disease: an interaction between genes and the environment. Am J Respir Crit Care Med 174:386-392

Venanzi S, Malerba G, Galavotti R, Lauciello MC, Trabetti E, Zanoni G, Pescollderungg L, Martinati LC, Boner AL, Pignatti PF (2001) Linkage to atopy on chromosome 19 in north-eastern Italian families with allergic asthma. Clin Exp Allergy 31:12201224

Vercelli D (2003) Learning from discrepancies: CD14 polymorphisms, atopy and the endotoxin switch. Clin Exp Allergy 33:153-155

Werfel T, Kirchhoff K, Wittmann M, Begemann G, Kapp A, Heidenreich F, Gotze O, Zwirner J (2000) Activated human T lymphocytes express a functional $\mathrm{C} 3 \mathrm{a}$ receptor. J Immunol 165:6599-6605

Zambelli-Weiner A, Ehrlich E, Stockton ML, Grant AV, Zhang S, Levett PN, Beaty TH, Barnes KC (2005) Evaluation of the CD14/-260 polymorphism and house dust endotoxin exposure in the Barbados Asthma Genetics Study. J Allergy Clin Immunol 115:1203-1209

Zhou W, Peng Q, Li K, Sacks SH (2007) Role of dendritic cell synthesis of complement in the allospecific $\mathrm{T}$ cell response. Mol Immunol 44:57-63 